\title{
BUNDISTS AND THE ISSUE OF EMIGRATION FROM POLAND AFTER THE SECOND WORLD WAR
}

\begin{abstract}
The main objective of this paper is to present a change in the attitudes among Bundists towards emigration in the post-war Poland. The program of the Jewish Labour Bund throughout its existence was based on three pillars: here-ness (doykayt), family-ness (mishpokhedikayt), and Jewish-ness (Yiddishkayt). After the Second World War some of them lost their significance. Many Jews, including Bundists, saw their future outside Poland. In the article I will show different attitudes of the members of the Bund towards emigration, as well as the reasons behind their choices: either to stay in Poland or to leave the country.
\end{abstract}

Key words: emigration and emigrationism, Jewish Labour Bund, post-war Poland.

\section{INTRODUCTION}

After the end of the Second World War, Holocaust survivors began to revive Jewish life in Poland. The reborn "Jewish street" was not able to proceed without Jewish political parties. One of these was the General Jewish Labor Bund, which was active between 1944 and 1949. Throughout the postwar period, the Bund, and the Tsukunft, its youth organisation, had roughly 3,000 registered members. The movement had been decimated during the war, and some of its ideals, like national and cultural autonomy, had lost currency in the absence of the Jewish shtetl.

\footnotetext{
* Martyna RUSINIAK-KARWAT, Institute of Political Studies Polish Academy of Sciences, Warsaw, Poland; e-mail: mrusiniak@isppan.waw.pl, ORCID: https://orcid.org/0000-0002-0494-1137 
One of the main pillars of Bundist ideology since the very founding of the party was doykayt (Yiddish, here-ness). That was why Bundists were radically opposed to any form of emigration, including mass migration to Palestine. The attitude towards emigration among Bundists, including in Poland, evolved after the end of the Second World War. At that point they began to openly support free emigration and immigration, namely the right to choose where to settle, regardless of whether the rationale was political or economic (Blatman, 2003; Rusiniak-Karwat, 2016; Slucki, 2012). They emphasised: "emigration has always existed and will continue to exist. I have nothing against ideological emigration" (Salo Fiszgrund's Speech, p. 156). At the same time, they continued to radically oppose illegal emigration (Bricha) (Semczyszyn, 2018).

Even if a certain portion of the Jewish people emigrate from Poland, this won't change their primary goal and ideal. Whether the Jewish working masses find themselves in America or in Palestine, in France or in Belgium, their task will remain the same - just as that of the Jews remaining in Poland - to fight for socialism hand in hand with the proletariat of a given country (Szuldenfrei, 1947, p. 1).

In the new postwar reality Bundists realised that they could not enter into a political debate with the Zionists, whose stipulation to rebuild the Jewish state was becoming more and more real, propelled by the Holocaust and the lack of prospects for rebuilding Jewish life in Poland. The Bund, which had been the most serious political option on the "Jewish street" and among Jewish workers in the 1930s, strove to deal with the new situation that emerged after the Holocaust and which essentially meant the marginalisation of the party (Pickhan, 2001). Its members had been decimated, while the Jewish street, which the Bund had so eagerly considered as reference, had been reduced to ruins and the brick dust rising from the rubble of the Warsaw ghetto.

\section{STAY OR LEAVE? THE ATTITUDE OF BUNDISTS TO EMIGRATION FROM POLAND. EMIGRATION AND EMIGRATIONISM}

Yet in spite of these circumstances Bundists were still dogmatically committed to rebuilding Jewish culture and to the party itself, and hence did not support mass emigration to the Land of Israel (emigrationism) (Rusiniak-Karwat, 2016, pp. 149-154).

Grzegorz (Grisza) Jaszuński wrote in the Bund Bulletin: "To emigrationism we oppose fighting here in this land, hand in hand with the Polish working class, to put in place such conditions of life as would ensure freedom and prosperity for all citizens regardless of their ethnicity or religion" (Jaszuński, 1945, p. 12). 
Jaszuński considered the idea of mass emigration to Palestine a nationalist utopia hampering the development of Jewish life in the diaspora and distracting people from the fight for their deserved political and social rights in their countries of residence - a utopia isolating Jews from the rest of the society.

The emigration issue and the wartime experiences of Bundists had an influence on how individual Bund committees as well as local and central party authorities worked. When it came to assessing the political situation, there were significant differences within the party between those who had survived the Second World War in German-occupied Poland and those who had spent it in the Soviet Union (with some minor exceptions). The trauma of the camps and gas chambers made the former the supporters of leaving Poland as they could not imagine continuing their lives in a Jewish 'cemetery'. Meanwhile, those who survived the war in the Soviet Union were more inclined to rebuild the Bund in Poland and to defer to Poland's new communist authorities, whose policies they accepted almost without any reservations. It seems they had forgotten that they were still "social-fascists" and that the Bolsheviks as well as their representatives in Poland could only see them as poputchiks (fellow travellers) who, when their usefulness ran its course, as the history of Soviet Russia amply showed, would be dropped in the dumpsters of history (like Victor Alter and Henryk Erlich, who had been murdered in Soviet prisons) (Rusiniak-Karwat, 2018).

After the Kielce pogrom the Bundist attitude to emigration became even more open, even though they continued to criticise Zionists for fearmongering. A number of Bundists also left Poland after July 1946. Members of the Bund even advocated allotting support to those emigrating in some special cases as part of a social benefits scheme. On these points, there were internal conflicts and tensions between two fractions in the party that had existed even before the outbreak of war in 1939. The first of these, the left wing, argued that the "Jewish street" had to be preserved in Poland, even in a microscopic form. They were all decidedly more anti-Zionist, but subgroups existed, though: some of these activists advocated a strict cooperation with the PPR (Polish Workers' Party) (Grzegorz Jaszuński). Another group supported an alliance with the PPS (Polish Socialist Party) as a separate section within the Polish party (Michał Szuldenfrei). A third group pushed for independence on the Polish political scene while rejecting other options, including emigration (Salo Fiszgrund) (Rusiniak-Karwat, 2016, p. 35; Szaynok, 2000, p. 320).

Their opponents, the right wing of the party (including Ignacy Falk and Avraham Zilbersztejn, the Tsukunft secretary in Warsaw), doubted the possibility of rebuilding the yishuv in postwar Poland. They even argued in favour of dissolving the party and emigrating. They were the first Bundists and Tsukunftists to leave Poland, refusing to accept the self-liquidation of the party (Szymon Zachariasz Collection, p. 155; Redakcja, Jugnt Weker, 1949, pp. 1-2; 'Trayshaft un mut...', 1949, pp. 37-38). 
The issue of emigration, including the departure of party members, was discussed to some extent at meetings of the Bund committees. Their participants proposed to increase agitation in favour of remaining in the country and to encourage Jews to reject visas. Bundists repeatedly emphasised that the borders of all countries, including the United States, should be open for Jews from Poland and other places. They stressed that "the Bund supports the repeal of the White Paper and unhindered Jewish immigration to any country, including Palestine" (CKŻP, Report No. 5, p. 26). They realised that with each Jew leaving Poland there was a smaller chance of continuing Jewish life there. Emigration undermined the very reasons for continuing the Bund itself. For how could the Bund continue if there was no Jewish proletariat?

At the same time, Bund representatives made critical statements about illegal Jewish emigration during meetings of the presidium of the Central Committee of Jews in Poland. The Bund criticised the Central Committee Memorandum to the Anglo-American Committee, drafted on behalf of all Polish Jews in February 1946. The memorandum called for free Jewish emigration to Palestine and the repeal of the White Paper. Meanwhile, on several occasions the Bund underlined that "It is a crime to restrict the whole issue of Jewish emigration to Palestine alone. It was argued that the concept of an exodus from Europe as well as subordinating Jewish life wholly and completely to the idea of Palestine is proof of infantile political thinking" (A.R., 1946, p. 3).

Meanwhile, the Bund's consent to Jews emigrating was a type of a modification of the party's pre-war slogans. It may be that Bundists realised that Jewish emigration from Poland was inevitable and that the party's continued existence would only be possible if large Jewish communities existed in the diaspora. Emigration to Palestine, where anti-Zionist slogans would no longer be relevant nor in line with the policies of the nascent Jewish state, would mean the end of the Bund. Moreover, the call for national and cultural autonomy, one of the main pillars of the party, would entirely lose its significance. The Bund would have to evolve from a party into a social/cultural association whose only task would be to cultivate Yiddish and Yiddishkayt, which was precisely what happened to the Bund in Israel after 1948.

Opposition to postwar emigration was also a feature of the ongoing political changes and was voiced by parties forming the so-called "democratic bloc" in Poland. In spite of having lived through dramatic experiences, most Jews returning from the USSR felt more affinity towards communism if they saw their future in Poland. Those who wanted to leave tended to sympathise with the Zionists, for whom Poland was only a transit country on the way to Palestine. When leaving Poland, they left nothing behind. Rebuilding life there had been an arduous task given the anti-Jewish atmosphere associated with the large number of Jews in the repressive communist apparatus and the anti-Jewish incidents proliferating in 1945-1947. A growing sense of alienation and fear pushed a large part of the Jewish community to emigrate and embrace Zionist, rather than socialist, ideals (Engel, 2001, pp. 213-224; Rusiniak-Karwat, 2016, passim). 


\title{
3. BUNDISTS FROM OUTSIDE POLAND ON EMIGRATION
}

To sum up the issue of migration, let me quote an opinion piece by Emanuel Scherer, who lived in the United States after the war, published in the Głos Bundu in Poland in 1946. Scherer emphasised that the Jews' right to emigrate should be a topic of debate, but emigration should not be presented as the only way out nor only to a Jewish state. His wordy argument is worth citing in full:

When calling upon Jews to leave their homes in Europe, are the Zionists certain that Palestine has the proper conditions to be colonized by masses of European refugees? [...] But let's leave room for doubt. Suppose the Zionists manage to overcome all of the difficulties which, in our opinion, are insurmountable. Suppose they even manage to create a Jewish state without a Jewish majority. So what? Will it make the so-called diaspora go out of existence? Will the Jews cease to live among other nations?

We take it for granted that regardless of whether the colonization of Palestine is successful or not, the vast majority of Jews shall remain outside of Palestine. As a matter of fact, if we look back to the time when an independent Judean state existed, there were other Jewish enclaves in the diaspora with an unquestionable national character. And often their spiritual culture was far superior to that of the metropolis (A.R., 1946, p. 3). ${ }^{1}$

Another opinion was held by Mordechai Canin (Tsanin), who had spent the Second World War in Palestine. In the Davar (the press outlet of Histadrut - the general labour union in Palestine) in 1946, he published an open letter to Bundists, in which he criticised their postwar stance on emigration and their traditionalism which failed to consider both the circumstances of Jewish life in Poland and the prospects of building a Jewish state in Palestine:

\begin{abstract}
Instead of boldly looking reality in the face, we Bundists have assumed a tactic of waiting for the situation to develop and of keeping ourselves calm by passing resolutions. But the Jews who spent five years fighting to survive don't want resolutions. They are demanding a concise, clear response to their troubles. The remnants of surviving Jewry are facing an alternative: to emigrate from countries where life has become impossible. You have struck Palestine, the only country interested in Jewish immigration with its heart and soul, from the map, being guided by prejudice and motives that have long since become irrelevant. We all know that other countries that could admit Jewish immigrants are shutting their doors to them. Comrades, you have stopped the hands of the clock and have completely forgotten what kind of times we are living in. You cling to views that gave up breath along with the first victims of the first gas chamber the Germans built in Poland, and instead of facing the truth, you are hiding behind the screen of defunct theories (Canin, 1946, p. 7).
\end{abstract}

Canin's words could be considered a representative opinion of a Jewish socialist raised by the Bund. His wartime experiences had led to an evolution of his views and made him pro-Palestine, leaning closer to Zionism.

\footnotetext{
${ }^{1}$ Scherer wrote also about the Jewish future in Poland in: Scherer, E. (1947), The Future of Jews, London.
} 


\section{EMIGRATION OF BUNDISTS. THEORY AND PRACTICE}

But theory is one thing, and practice is another. Let us now discuss a few examples of Bundists emigration. Bernard Goldstein and Vladka Meed left for New York right after the war. He had been active in the underground Bund Committee, while she had been a member of the Tsukunft in the Warsaw ghetto and later on the Aryan side, as well as a member of the Jewish Fighting Organisation. Goldstein left fearing for his life, as he was wanted by the authorities. The Bund informed of his departure in party press. The Central Party Committee wanted to reassure other Bundists. The reason given for his departure was his poor health, which Goldstein supposedly wanted to 'repair' in the West ('Kh. Bernard...', 1946, p. 2)

At the beginning of 1947, Leo Finkelsztejn (who survived the war in the USSR) left for the United States with Ignacy Falk on a mission to the Polish Bund representation in America and stayed there for health-related reasons. The members of the Bund Central Committee in Poland urged him to return as soon as possible. His forced (due to health reasons) absence was seen as an ideological escape. They sent him official letters not to prolong his stay. His leave was a violation of Bundist ideology and was treated almost on a par with treason and the implementation of Zionist slogans. It gave the impression that Finkelsztejn, one of the foremost Bundists in postwar Poland, had used an opportunity to leave the country; basically to escape. This could be used by Zionists against Bundists in ideological debates. The actions of one of the leading Bundist activists in the country could be interpreted as the party's tacit consent for emigration, which is something that the left wing of the Bund wanted to avoid at all cost, fearing it would discredit them. Continued Bundist activity would then lose its purpose (Dina, 1951, p. 22).

From the perspective of later events and in light of the liquidation of all Jewish parties in Polish People's Republic, we can say that the Bundists' faith (particularly of the left wing) in the continued existence of the Bund in Poland and in stopping Jewish emigration was nothing short of utopian. After leaving Poland, most Bundists bound their fates to Bund committees in the countries of their destination, which became something of a substitute family, bundishe mishpokhe (Yiddish, Bundists family), rather than a political party (Wolff, 2011, p. 79). Without a doubt many leading Bundists did not imagine a future outside of Poland. There they were leaders whereas in other countries the top party positions were already filled and they would have to become ordinary members. Age was also a factor (most had been born before 1900). Not everyone could or wanted to learn a new profession and language. Many Bund leaders in Poland held office jobs. They realised that abroad they would be blue 
collar workers. For example, Szechatow was an accountant in Poland; after moving to Sweden, he worked in a radio factory (Blomqvist, 2020, passim; Rusiniak-Karwat, 2016, passim).

\section{MOTIVATION BEHIND DECISIONS TO EMIGRATE}

There were many factors that influenced Bundist activists' attitude to emigration and emigrationism. These included the traditional ideological line of the party, viewed as the advocate of the Jewish proletariat in ensuring the latter's proper national and cultural autonomy; a lack of faith in the Zionist program, but also personal and professional reasons for the older generation of Bundists. Demographic changes in the structure of the Jewish population (considering it was mostly young people who had survived the Holocaust), hopes of a better tomorrow in their own state in Palestine - all of these considerations rendered the Bundist program somewhat obsolete given the expectations and aspirations of the Jewish community and even of the members of the party or its affiliate organisations.

The actions of the Bund leadership did not prevent the emigration of party members and other Jews from Poland. The greatest number of Bundists left the country after the Kielce pogrom as well as in the summer of 1948, as the self-liquidation of the party gained momentum. Many 'foot soldier' members of the party left Poland legally as soon as the war ended. Leaving illegally, with the help of guides, on their own or in small groups, the movement started in the summer of 1948 with the members of the Bund Central Committee, the Tsukunft, as well as local committee leaders, who did not want to or could not wait for a passport and a permission to emigrate. At this point I should emphasise that Bundists fled illegally when legal emigration to the newly founded State of Israel was already possible after May 1948 (AIPN Kr 07/1694; AIPN Ld PF 12/3107; 'Trayshaft un mut...', 1949, pp. 37-38).

The whole emigration scheme only worked by dint of the material support of Bundist organisations in the West, mainly in the United States. Bundists justified their decision to leave citing the following reasons:

1. Dissatisfaction with the political situation and refusal to adapt to the new reality,

2. Refusal to 'repent,' renounce Bundist ideology and join the Polish United Workers' Party,

3. Fear of being arrested for 'counterrevolutionary activity' (1947 saw the arrest of David Klin, a member of the underground Bund committee in the Warsaw ghetto; 1949 saw the arrest of Lieber Gottlob, who had returned to Poland from Great Britain in 1947, having served in Anders' Army) (AIPN Kr 07/1694; AIPN Ld PF 12/3107). 


\section{MIGRATION ROUTES AND CHANNELS}

Many of those who had not planned to leave Poland earlier, left after 1948. Different migration routes and channels were used. Shulim Rozenberg described his departure as follows:

In 1948 the witch-hunt against the Bundists started, for its links with the Bund in America, because the Bund in America is against communism. And they told us the Bund had to be shut down and we had to go over to the workers' party, PPR. When we heard that, we made a meeting of the Zukunft Central Committee and the Bund Central Committee separately, and we decided we were leaving. (...) And groups started being organized to emigrate. Before that I'd never thought to leave, because I was waiting for my brother Ksil to be released from the camp. On 15 May 1948 my brother Ksil came back from Russia. (...)

When there was the decision to leave Poland, there was a group of 6 of us, and we went to Katowice (...). In Katowice was the boss who was running the emigration. I don't know who he was. We were to go in the night, over the border, and in the morning we were in Prague. I went with my wife, my brother Ksil, my friend who I lived with after the war, Leon Krolicki, and there was also one of the editors of the Folkszeitung with us, a writer and historian, Mordechaj Bernsztajn. From Prague we had to go to Germany. And we went by train to the border, and from the border by bus to Feldafing [Germany]. We arrived in Feldafing in the night; they saw there was a pregnant woman with us, so they took us straight away to a private family. We stayed with those private people those few weeks that we were in Feldafing. For a visa to America you had to wait a year, a year and a half, and I didn't want the child to be born in Germany. And we went to Ulm and from Ulm there was a group that was going to Paris. And we arrived in Paris on 22 August 1948 (Rozenberg: interview, 2006).

Icchak Luden left Poland with Zionists legally via Szczecin in 1948 on a ship called Beniowski. He reached Israel on 19 December 1948, having gone through France (Icchak Luden: interview, 2015). Most Jews left illegally through the green border with Czechoslovakia near Kudowa. Some of these fugitives initially stopped in Germany. According to the records of the Provincial Public Security Office in Łódź, they 'fled' and 'disappeared in an unknown direction.' Some very quickly made it to France, where they received help from other Bundists and they settled there. Others, like Mordechai Bernstein, spent several years in Germany, where they continued to be active as Bundists in DP camps (Rusiniak-Karwat, 2016, p. 88). Many Bundists also eventually settled in Australia, in spite of earlier declarations that they were going to the United States as they had trouble getting entry visas. The already mentioned Szechatow went to Sweden with his family. It was also through Sweden that Lucjan Blit's daughters reached London (Blomqvist, 2020; Vladka Blit: interview, 2007).

Only a handful of former Bundists remained in Poland after 1950. Owing to the help of fellow Bundists from Belgium and France and the invitations they sent, some of these joined them later (Roman Blit's Collection, folder 13). They left for Australia, for example Israel Zajd (AIPN, BU 1548/390), France - Ignacy Feldman (Marian Feldman: interview, 2012), USA - Lieber (Lipek) Gottlob, Is- 
rael - a large group from Tarnów, as well as Josef Frajnd. The last ones to leave, including even those from the left wing of the party, left Poland at the end of the 1960s as a result of the 1968 anti-Zionist campaign targeting Jews. Most of them chose Israel as their destination (Salo Fiszgrund) (AIPN, BU 1268/19262).

\section{THOSE WHO REMAINED}

There were also Bundists who only saw their future in Poland. Their reasons for staying were diverse. Some of them even joined the Polish United Workers' Party. One reason for staying was their old age and health problems. Those who stayed were mostly around 60 years of age, for example Zdzisław Muszkat. They realised that starting everything anew at their age and with their faltering health could simply fail. Moreover, they enjoyed financial stability in Poland while they did not know what awaited them abroad. Another reason was having a Polish spouse - the case of Ignacy Samsonowicz. Inability to speak any foreign language, particularly English and French, was also an obstacle. Many, like Luba Blum-Bielicka, also did not want to leave (even if their children had left) because they considered Poland their homeland, and it was there - regardless of communism - that they saw their future. Another, probably the most important, reason for staying was financial status - having one's own large apartment and holding an important public post, like Dr. Michał Szuldenfrei and Grzegorz Jaszuński. Others, like Marek Edelman, a medical student in Łódź, claimed that someone must stay behind as a "guardian of the graves" of Bundist comrades (Rusiniak-Karwat, 2016, passim).

All those who stayed in Poland shared not only a common Bundist past but also a common present. They devoted themselves to their families, but also worked to help others. Most remained faithful to their ideals. They also tried to keep in touch with one another and with Bundists abroad in the West. The few who stayed in Poland included Irena Jaszuńska, who many years later regretted that she had not emigrated. If she had, she would have been able to live out her days among those she was close to in the Bundist family (Roman Blit's Collection, folder 13).

\section{CONCLUSIONS}

In conclusion, the attitude of the Bund towards emigration and emigrationism was one of the main ideological pillars of the party which was anti-Zionism. In the new post-war reality Bundists realised that some of their main pillars had to be modified in order for the Bund to have a chance to continue existing. Hence, they changed their 
attitude towards emigration. At the same time they fought for freedom to choose the destination country to settle after leaving Poland. They believed that existence of the party would be possible only when established larger Jewish communities would be established in the diaspora (dispersed) outside the Land of Israel. The emigration of Bundists from Poland continued throughout the 1940s after the Second World War. Most of them decided to leave in the summer of 1948 when a self-liquidation of the Bund in Poland was already a foregone conclusion. That way many of them avoided political repressions. Many chose France, the United States, and Australia as their destination countries. Thus they joined the ranks of Bund organisations in these countries and continued their political activities.

\section{REFERENCES}

A.R. (1946), 'Naród żydowski a «państwo żydowskie»', Głos Bundu, 1.

BLATMAN, D. (2003), For Our Freedom and Yours. The Jewish Labour Bund in Poland 19391949, London-Portland: Vallentine Mitchell, pp. 164-218.

BLOMQVIST, H. (2020), Socialism på jiddisch: judiska Arbeter Bund i Sverige, Stockholm: Carlsons.

CANIN, M. (1946), 'Do towarzyszy z «Bundu»', Nasze Stowo (Organ zjednoczonej żydowskiej partii syjonistycznej Poalej Syjon), 2-3.

DINA (1951), 'Leo Finkelsztejn', Unzer Tsait, 9.

ENGEL, D. (2001), 'The Bund after the Holocaust: Between Renewal and Self-Liquidation', [in:] JACOBS, J. (ed.), Jewish Politics in Eastern Europe: The Bund at 100, New York: New York University Press. https://doi.org/10.1057/9781403913883_16

JASZUŃSKI, G. (1945), 'Emigracja i emigracjonizm', Biuletyn Bundu, 3.

Kh. Bernard gekumen ka Nyu-York (1946), Folkcajtung, 2-3.

PICKHAN, G. (2001), "Gegen den Strom” der Algemeine Jüdushe Arbeiterbund "BUND” in Polen 1918-1939, Stuttgart-München: Deutsche Verlags-Anstalt.

Redakcja (1949), 'Der «Jugnt Weker» dersheynt vider; Di «Tsukunft» in Poyln hot nisht kapitulirt', Jugnt Weker, 1.

RUSINIAK-KARWAT, M. (2016), Nowe życie na zgliszczach. Bund w Polsce w latach 1944-1949, Warsaw: ISP PAN.

RUSINIAK-KARWAT, M. (2018), 'Bundists in the Soviet Union during Second World War', [in:] PINTO, V. (ed.), Bundist Legacy after Second World War, Leiden-Boston: Brill, pp. 7-17, https://doi.org/10.1163/9789004361768_003

SCHERER, E. (1947), The Future of Jews, London.

SEMCZYSZYN, M. (2018), 'Nielegalna emigracja Żydów z Polski 1944-1947 - kontekst międzynarodowy', Dzieje Najnowsze, 1, pp. 95-121. https://doi.org/10.12775/DN.2018.1.05

SLUCKI, D. (2012), The International Jewish Labor Bund after 1945. Toward a Global History, Chapter II: "On the Ruins of the Old World. The Bund in Central and Eastern Europe", Subsection: "Between Fascism and Communism", New Brunswick-New Jersey-London: Rutgers University Press, pp. 56-74.

SZAYNOK, B. (2000), 'Bund i komuniści żydowscy w Polsce po 1945 r.', [in:] TYCH, F. and HENSEL, J. (eds.) Bund. 100 lat historii. 1897-1997, Warsaw: Żydowski Instytut Historyczny. SZULDENFREI, M. (1947), '50 lat Bundu', Głos Bundu, 8-9.

'Trayshaft un mut. Deklaratzye vegn der bundisher yugnt in Poyln' (1949), Unzer Tsait, 4-5.

WOLFF, F. (2011), 'The Collateral Prisoner. A Bundist Holocaust Survivor between Nazi Perpetrators, Anti-Communism and British World Politics', The International of Communist Studies, 24, p. 79. 


\section{ARCHIVAL SOURCES}

AIPN Kr 07/1694 - documents about Lieber Gottlob, Archives of the Institute of National Remembrance (Archiwum Instytutu Pamięci Narodowej, AIPN).

AIPN Ld PF12/3107 - documents about Dawid Klin, Archives of the Institute of National Remembrance (Archiwum Instytutu Pamięci Narodowej, AIPN).

AIPN, BU 1548/390 - passport files of Izrael Zajd, Archives of the Institute of National Remembrance (Archiwum Instytutu Pamięci Narodowej, AIPN).

AIPN, BU 1268/19262 - passport files of Salo Fiszgrund, Archives of the Institute of National Remembrance (Archiwum Instytutu Pamięci Narodowej, AIPN).

Ref. No. 303/I/11, Report No. 5, 29 I 1946 (CKŻP. Report No. 5), Centralny Komitet Żydów w Polsce. Prezydium i Sekretariat. 1945-1950 [Central Committee of Jews in Poland. The Presidium and Secretariat. 1945-1950, CKŻP], Archives of the Jewish Historical Institute in Warsaw (Archiwum Żydowskiego Instytutu Historycznego, AŻIH).

Ref. No. 303/I/20, Report No. 31, 24 III 1947 (Salo Fiszgrund's Speech), Centralny Komitet Żydów w Polsce. Prezydium i Sekretariat. 1945-1950 [Central Committee of Jews in Poland. The Presidium and Secretariat. 1945-1950, CKŻP], Archives of the Jewish Historical Institute in Warsaw (Archiwum Żydowskiego Instytutu Historycznego, AŻIH).

RG 1476 - Roman Blit's Collection, folder 13, New York: YIVO Archives.

Spuścizna Szymona Zachariasza [Szymon Zachariasz Collection], Ref. No. 476/28, Archives of Modern Records (Archiwum Akt Nowych, AAN).

\section{INTERVIEWS}

Blit Vladka (2007), (in the author's private collection).

Feldman Marian (2012), (in the author's private collection).

Luden Icchak (2015), (in the author's private collection).

Rozenberg Szulim (2006), online: https://www.centropa.org/biography/szulim-rozenberg [accessed on: 21.03.2021]. 